\title{
PENGARUH KETERAMPILAN, ORIENTASI PASAR, DAN JARINGAN USAHA TERHADAP KINERJA UMKM MELALUI KOMPETENSI WIRAUSAHA
}

\author{
Andrean Yusuf ${ }^{1}$, Lydiawati Soelaiman² \\ ${ }^{1}$ Program Studi Manajemen, Fakultas Ekonomi dan Bisnis, Universitas Tarumanagara \\ Email: andreanyusuff61@gmail.com \\ ${ }^{2}$ Program Studi Manajemen, Fakultas Ekonomi dan Bisnis, Universitas Tarumanagara* \\ Email: lydiawatis@fe.untar.ac.id \\ *Penulis Korespondensi
}

Masuk : 15-01-2022, revisi: 20-01-2022, diterima untuk diterbitkan : 25-01-2022

\begin{abstract}
ABSTRAK
Penelitian ini bertujuan untuk mengetahui pengaruh keterampilan kewirausahaan, orientasi pasar, dan jaringan usaha terhadap kinerja usaha UMKM di Jakarta dengan kompetensi wirausaha sebagai variabel mediasi. Peneliti menyebarkan kuesioner pada seluruh pemilik usaha UMKM di Jakarta dengan menggunakan purposive dan snowball sampling. Metode analisis data dalam penelitian ini yaitu metode kuantitatif dengan menggunakan Structural Equation Modeling (SEM), yang diolah dengan bantuan Software SmartPLS 3. Hasil dari penelitian menunjukkan keterampilan kewirausahaan dan jaringan usaha tidak memiliki pengaruh signifikan terhadap kompetensi wirausaha, tetapi orientasi pasar memiliki pengaruh yang signifikan terhadap kompetensi wirausaha sedangkan kompetensi wirausaha memiliki pengaruh yang signifikan terhadap kinerja usaha. Hasil penelitian juga menunjukkan kompetensi wirausaha tidak mampu memediasi keterampilan wirausaha maupun jaringan usaha terhadap kinerja usaha UMKM di Jakarta, tetapi kompetensi wirausaha mampu memediasi orientasi pasar terhadap kinerja usaha UMKM di Jakarta. Hasil penelitian diharapkan memberikan manfaat bagi pemilik usaha UMKM di Jakarta untuk meningkatkan keterampilan-keterampilan, jaringan usaha, orientasi pasar, kompetensi wirausaha dalam rangka mengembangkan kinerja usaha yang lebih baik.
\end{abstract}

Kata Kunci: Keterampilan Kewirausahaan, Orientasi Pasar, Jaringan Usaha, Kompetensi Wirausaha, Kinerja Usaha

\section{ABSTRACT}

The purpose of this study was to determine the effect of entrepreneurial skills, market orientation, and business networks on the business performance of MSMEs in Jakarta with entrepreneurial competence as a mediating variable. Researchers distributed questionnaires to SME business owners in Jakarta using purposive and snowball sampling. The data analysis method in this study is a quantitative method using Structural Equation Modelling (SEM), which is processed by SmartPLS 3 Software. The results of this study indicate that entrepreneurial skills and business networks do not have a significant effect on entrepreneurial competence, but market orientation has a significant influence on entrepreneurial competence, while entrepreneurial competence has a significant influence on business performance. The results also show that entrepreneurial competence is not able to mediate entrepreneurial skills and business networks on SME business performance in Jakarta, but entrepreneurial competence is able to mediate market orientation to SME business performance in Jakarta. The results of the research are expected to provide benefits for SME business owners in Jakarta to improve skills, business networks, market orientation, entrepreneurial competence for better business performance.

Keywords: Entrepreneurship Skills, Market Orientation, Business Network, Entrepreneurship Competency, Business Performance

\section{PENDAHULUAN}

\section{Latar Belakang}

UMKM memiliki peran penting dalam pembangunan suatu bangsa karena keberadaan UMKM dapat menyediakan lapangan kerja, menciptakan keseimbangan pendapatan sosial dan 
mendukung pelatihan bagi para penduduk yang kebanyakan tidak terlatih atau unskilled. UMKM juga dapat mengembangkan kreatifitas masyarakat dan juga mempertahankan kearifan lokal, UMKM yang berbeda-beda satu dengan yang lainnya akan menimbulkan ciri khas usaha, sehingga mudah dikenali masyarakat (Hafsah, M. Jafar, 2004).

Seorang pemilik UMKM tentunya memerlukan berbagai keterampilan dalam mengembangkan kompetensi khusus pengelolaan suatu perusahaan. Keterampilan berwirausaha merupakan norma subjektif yang dapat mendorong individu lebih kompeten dalam menjalankan usahanya. Keterampilan wirausaha dapat menjadi faktor yang mendorong pelaku usaha untuk mempertahankan kualitas produk yang dimiliki dan citra baik dari pelanggan. Jika pelaku usaha mampu menuangkan segala keterampilan yang dimiliki serta pengetahuan yang dimiliki, maka akan memicu berkembangnya keterampilan wirausaha (Kutzhanova et al., 2009).

Di dalam proses pengembangan UMKM, orientasi pasar sangat diperlukan untuk membantu perusahaan dalam mendekati dan memahami pasar yang selanjutnya dapat menentukan strategi yang tepat (Vorhies et al., 2009). Hal ini dikarenakan orientasi pasar merupakan kemampuan perusahaan dalam mengadaptasi perubahan kondisi pasar. Baker dan Sinkula (2009) menyoroti bahwa orientasi pasar dapat mempengaruhi kompetensi kewirausahaan yang melakukan inovasi pada produk dan jasa yang diberikan. Inti dari orientasi pasar adalah menempatkan kebutuhan pelanggan sebagai yang utama dari strategi dan operasi perusahaan. Oleh sebab itu, orientasi pasar dipengaruhi oleh perubahan kebutuhan pasar dan preferensi pelanggan yang lebih baik (Shehu dan Mahmood, 2014).

Jaringan usaha juga diperlukan oleh UMKM dalam mendukung keberhasilan usahanya. Jaringan usaha dianggap sebagai penghubung antara dimensi sosial dan perilaku ekonomi manusia. Jaringan usaha dapat membantu hal-hal dasar, seperti mencari supplier maupun buyer, memasarkan produk/jasa yang ditawarkan perusahaan, menjalin kerjasama, dan sebagainya. Jaringan usaha memiliki dampak yang signifikan pada pertumbuhan dan tahap perkembangan suatu perusahaan. Jaringan usaha merupakan salah satu aset paling kuat yang bisa dimiliki oleh siapa pun dimana terdapat ketersediaan akses terhadap kuasa, informasi, pengetahuan dan modal serta jaringan lainnya (Sengupta, 2011).

Selain faktor-faktor di atas, kompetensi kewirausahaan diperlukan untuk membantu mengoperasikan kewirausahaan di perusahaan (Mitchelmore dan Rowley, 2010). Kompetensi kewirausahaan merupakan kemampuan dalam memanfaatkan sumber daya yang dimiliki dalam upaya meningkatkan kinerja usaha. Bird (1995) menyatakan bahwa kompetensi kewirausahaan memiliki hubungan dengan pertumbuhan dan keberlanjutan sebuah perusahaan. Menurut Mangkunegara (2005), seseorang yang mempunyai kemampuan lebih dapat menjadi faktor dasar kompetensi wirausaha, sehingga dapat membuatnya berbeda dengan seorang yang mempunyai kemampuan rata-rata.

Penelitian ini diharapkan mampu memberikan gambaran bagi para pelaku Usaha Mikro Kecil dan Menengah (UMKM) untuk dapat meningkatkan kinerjanya melalui keterampilan berwirausaha, orientasi pasar, dan jaringan usaha, sehingga dapat menggapai target pasar yang tepat dan juga memasarkan produk dengan pasar yang lebih luas. 


\section{Kajian teori \\ Keterampilan kewirausahaan}

Menurut Pyysiäinen et al. (2006), keterampilan kewirausahaan didefinisikan sebagai kemungkinan belajar dan mengadopsi secara eksklusif karakteristik yang penting untuk melakukan tugas kewirausahaan yang melibatkan interaksi dalam lingkungan sosial dan material. Menurut Kim et al. (2011), keterampilan kewirausahaan merupakan hal yang sangat penting untuk menentukan penggunaan sumber daya untuk mencapai keunggulan kompetitif yang berkontribusi pada kinerja, pertumbuhan, dan profitabilitas perusahaan.

Berdasarkan definisi keterampilan kewirausahaan tersebut, dapat disimpulkan bahwa keterampilan kewirausahaan merupakan kegiatan atau pengetahuan yang dapat membantu perusahaan untuk mencapai keunggulan kompetitif yang akan berkontribusi pada kinerja, pertumbuhan, dan profitabilitas perusahaan.

\section{Orientasi Pasar}

Kohli and Jaworski (1990) mendefinisikan orientasi pasar sebagai upaya yang dilakukan oleh perusahaan untuk melakukan promosi, pengumpulan, dan penyebaran informasi dalam upaya memenuhi pelanggan kebutuhan. Menurut Narver dan Slater (1990), orientasi pasar didefinisikan sebagai budaya organisasi yang meningkatkan kompetensi untuk menciptakan nilai superior bagi pembeli yang menentukan kinerja yang unggul.

Sehingga dapat disimpulkan orientasi pasar merupakan sebuah kemampuan dalam promosi dan respons perusahaan untuk memenuhi kebutuhan pelanggan.

\section{Jaringan Usaha}

Jaringan usaha merupakan kemampuan untuk mengelola satu hubungan dengan pihak lain yang secara tidak langsung diperkenalkan oleh rekan langsungnya. Menurut Bird (1995), jaringan usaha didefinisikan sebagai sumber daya yang berharga dalam membentuk kompetensi khusus untuk mengembangkan bisnis.

Dapat disimpulkan berdasarkan definisi jaringan usaha diatas bahwa jaringan usaha merupakan hubungan dengan pihak lain yang dapat membantu usaha dalam mengembangkan bisnis.

\section{Kompetensi Wirausaha}

Menurut Barney (1991) dan Grant (1991), kompetensi wirausaha sebagai sumber daya yang berharga dan tak ada bandingannya yang menghasilkan kemampuan untuk memfasilitasi kinerja organisasi. Menurut Man et al. (2002), kompetensi wirausaha dapat terlihat dari kemampuan wirausaha yang memiliki ciri-ciri kepribadian, keterampilan dan pengetahuan, yang mendukung kesuksesan suatu pekerjaan.

Berdasarkan definisi di atas, maka dapat disimpulkan bahwa kompetensi wirausaha merupakan karakteristik yang mendasar dan spesifik yang berupa pengetahuan, motif, sifat, citra diri, peran sosial, dan keterampilan untuk melakukan pekerjaan dengan sukses.

\section{Kinerja Usaha}

Menurut Gates (1999), kinerja usaha merupakan cerminan matriks kinerja dalam menerapkan strategi dalam organisasi. Menurut Smith dan Reece (1999), kinerja usaha merupakan kemampuan operasional untuk memenuhi keinginan pemegang saham utama perusahaan, dan itu 
harus dinilai untuk mengukur prestasi organisasi. Kinerja usaha merupakan ukuran keberhasilan dalam perkembangan usaha (Dita \& Soelaiman, 2021).

Definisi dari kinerja usaha dapat disimpulkan merupakan kemampuan operasional untuk mengukur prestasi suatu usaha.

\section{Keterkaitan antar variabel}

Penelitian sebelumnya menunjukkan bahwa keterampilan kewirausahaan dapat berkontribusi pada kinerja, pertumbuhan, dan profitabilitas perusahaan (Kim et al, 2011). Phelan dan Sharpley (2012) berpendapat bahwa wirausaha memerlukan berbagai keterampilan untuk mengembangkan kompetensi, khususnya dalam mengelola suatu perusahaan. Menurut Baker dan Sinkula (2009), orientasi pasar juga dapat mempengaruhi kompetensi kewirausahaan untuk berinovasi produk dan layanan yang ada, dan perusahaan dapat mengembangkan bauran pemasaran untuk menargetkan pelanggan secara spesifik. Tidak kalah penting, jaringan usaha juga diperlukan dalam mengembangkan bisnis karena jaringan usaha merupakan kemampuan khusus yang dapat meningkatkan kinerja perusahaan (Ahmad et al., 2010).

Kompetensi kewirausahaan termasuk pengetahuan yang berharga, keterampilan dan kemampuan yang dapat membantu perusahaan menghasilkan keunggulan kompetitif (Tehseen dan Ramayah, 2015). Dalam kewirausahaan, kompetensi terkait dengan permulaan, pertumbuhan, dan keberlanjutan yang memfasilitasi kinerja organisasi.

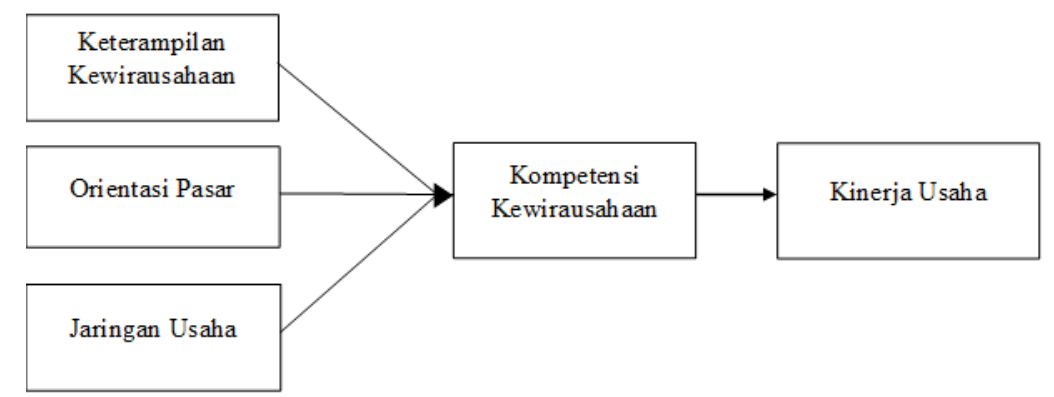

Gambar 1. Model penelitian

Hipotesis model penelitian adalah sebagai berikut:

H1: Keterampilan kewirausahaan berpengaruh positif terhadap kompetensi kewirausahaan.

$\mathrm{H} 2$ : Orientasi pasar berpengaruh positif terhadap kompetensi kewirausahaan.

H3: Jaringan usaha berpengaruh positif terhadap kompetensi kewirausahaan.

H4: Kompetensi kewirausahaan berpengaruh positif terhadap kinerja usaha.

H5: Kompetensi kewirausahaan memediasi keterampilan kewirausahaan dengan kinerja usaha

H6: Kompetensi kewirausahaan mampu memediasi orientasi pasar dengan kinerja usaha.

H7: Kompetensi kewirausahaan mampu memediasi jaringan usaha dengan kinerja usaha.

\section{METODE PENELITIAN}

Metode penelitian yang digunakan adalah penelitian kuantitatif. Desain penelitian yang digunakan dalam penelitian ini adalah kausalitas. Populasi yang diteliti merupakan para pemilik usaha UMKM di Jakarta. Penelitian menggunakan snowball sampling dan purposive sampling. Kriteria sampel yang digunakan ialah para pemilik usaha UMKM di Jakarta dengan lama usaha minimal 1 tahun. Jumlah sampel dalam penelitian sebanyak 100 pelaku UMKM. Dalam penelitian ini, peneliti menggunakan Partial Least Square yang merupakan salah satu metode analisis data menggunakan Structural Equation Modeling (SEM). 


\section{HASIL DAN PEMBAHASAN}

\section{Uji validitas}

Data yang diperoleh diuji menggunakan convergent validity melalui nilai Average Variance Extracted (AVE) dan loading factor yang ada dalam setiap indikator. Nilai convergent validity dapat terpenuhi atau dikatakan valid jika nilai AVE lebih besar dari 0,50. Nilai dapat dikatakan valid apabila loding factor indicator berada diatas 0,50 . Hasil uji validitas dapat dilihat dalam Gambar 2.

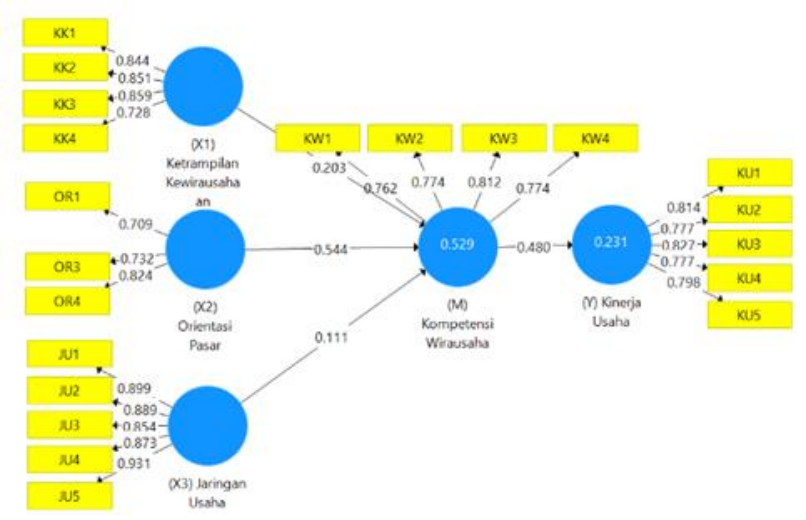

Gambar 2. Hasil analisis convergent validity

\section{Uji Reliabilitas}

Menurut Sukadji (2000), uji reliabilitas untuk mengukur seberapa besar alat tes mampu mengukur sasaran yang diukur secara konsisten. Dalam pengambilan keputusan untuk pengujian reliabilitas yaitu suatu konstruk atau variabel dikatakan reliabel jika memberikan nilai Cronbach's alpha $>0,60$.

Tabel 1. Hasil uji reliabilitas

\begin{tabular}{|c|c|}
\hline Variabel & Cronbach ' alpha \\
\hline Keterampilan Kewirausahaan & 0,842 \\
\hline Orientasi Pasar & 0,623 \\
\hline Jaringan Usaha & 0,935 \\
\hline Komepetensi Wirausaha & 0,863 \\
\hline
\end{tabular}

\section{Hasil Uji $\mathbf{R}^{2}$}

Koefisien determinasi bertujuan untuk mengukur besarnya persentase jumlah variasi dari variabel dependen atau untuk mengukur pengaruh dari variabel independen terhadap variabel dependen. Hasil analisis dari koefisien determinasi dapat dihitung dengan cara mengalikan $R$ square $\left(\mathrm{R}^{2}\right)$ dengan $100 \%$.

Tabel 2. Hasil uji $\mathrm{R}^{2}$

\begin{tabular}{|c|c|c|}
\hline & R-Square & Adjusted R-Square \\
\hline Kinerja Usaha (Y) & 0,556 & 0,538 \\
\hline
\end{tabular}

Berdasarkan hasil dari Tabel 2, besar $R$-square sebesar 0,556. Artinya sebesar 55,6\% variabel kinerja usaha dapat dijelaskan oleh variabel keterampilan kewirausahaan, orientasi pasar, jaringan usaha, dan kompetensi wirausaha, sedangkan sisanya sebesar 44,4\%, dijelaskan oleh variabel lainnya yang tidak diteliti oleh peneliti. 


\section{Hasil Uji $\mathbf{Q}^{2}$}

$Q$-Square $\left(\mathrm{Q}^{2}\right)$ memiliki nilai $\mathrm{Q}^{2}$ yang dihasilkan melalui prosedur blindfolding.

Tabel 3. Hasil uji $Q^{2}$

\begin{tabular}{|c|c|}
\hline Variabel & $\mathbf{Q}^{\mathbf{2}}$ \\
\hline Komepetensi Wirausaha & 0,307 \\
\hline Kinerja Usaha & 0,128 \\
\hline
\end{tabular}

Hasil dari Tabel 3 menunjukkan bahwa nilai $\mathrm{Q}^{2}$ lebih besar dari 0 (nol), sehingga dapat disimpulkan bahwa semua variabel memiliki relevansi prediktif atau predictive relevance.

\section{Hasil uji $\mathbf{f}^{2}$}

Uji effect size digunakan untuk mengetahui seberapa besar efek yang diberikan terhadap variabel tertentu jika tidak diteliti dalam penelitian ini.

Tabel 4. Hasil uji $\mathrm{f}^{2}$

\begin{tabular}{|c|c|}
\hline Variabel & $\mathbf{f}^{\mathbf{2}}$ \\
\hline Keterampilan Kewirausahaan & 0,034 \\
\hline Orientasi Pasar & 0,458 \\
\hline Jaringan Usaha & 0,003 \\
\hline Kompetensi Wirausaha & 0,302 \\
\hline
\end{tabular}

Dalam Tabel 4, dapat dilihat nilai effect size dalam keterampilan kewirausahaan terhadap kinerja usaha sebesar 0,034 (pengaruh kecil), orientasi pasar terhadap kinerja usaha sebesar 0,458 (pengaruh besar), jaringan usaha terhadap kinerja usaha sebesar 0,003 (pengaruh kecil), dan variabel kompetensi wirausaha sebesar 0,302 (pengaruh besar).

\section{Hasil uji Goodness of Fit (GoF)}

Uji Goodness of Fit dilakukan pada suatu penelitian yang bertujuan untuk mengetahui bagaimana tingkat kesesuaian dan kelayakan dalam suatu model penelitian. Penelitian ini memiliki hasil GoF yang besar, yaitu sebesar 0,614 yang artinya nilai interpretasi model besar.

\section{Hasil uji hipotesis}

Pengujian hipotesis pada penelitian ini bertujuan untuk dapat mengetahui apakah hipotesis yang telah dibuat dapat diterima atau ditolak.

Tabel 5. Hasil uji hipotesis

Sumber: Hasil pengolahan data dengan menggunakan software SmartPLS versi 3

\begin{tabular}{|l|c|c|c|c|}
\hline \multicolumn{1}{|c|}{ Variabel } & Nilai Sampel & $\boldsymbol{t}$-stat & $\boldsymbol{p}$-values & Keterangan \\
\hline $\begin{array}{l}\text { Keterampilan Kewirausahaan } \rightarrow \text { Kompetensi } \\
\text { Wirausaha }\end{array}$ & 0,183 & 1,286 & 0,199 & Tidak didukung \\
\hline Orientasi Pasar $\rightarrow$ Kompetensi Wirausaha & 0,589 & 5,630 & 0,000 & Didukung \\
\hline Jaringan Usaha $\rightarrow$ Kompetensi Wirausaha & 0,047 & 0,513 & 0,608 & Tidak didukung \\
\hline Kompetensi Wirausaha $\rightarrow$ Kinerja Usaha & 0,482 & 6,483 & 0,000 & Didukung \\
\hline $\begin{array}{l}\text { Keterampilan Kewirausahaan } \rightarrow \text { Kompetensi } \\
\text { Wirausaha } \rightarrow \text { Kinerja Usaha }\end{array}$ & 0,088 & 1,177 & 0,240 & Tidak didukung \\
\hline $\begin{array}{l}\text { Orientasi Pasar } \rightarrow \text { Kompetensi Wirausaha } \rightarrow \text { Kinerja } \\
\text { Usaha }\end{array}$ & 0,284 & 4,009 & 0,000 & Didukung \\
\hline $\begin{array}{l}\text { Jaringan Usaha } \rightarrow \text { Kompetensi Wirausaha } \rightarrow \text { Kineja } \\
\text { Usaha }\end{array}$ & 0,023 & 0,485 & 0,628 & Tidak didukung \\
\hline
\end{tabular}


Berdasarkan hasil pengujian hipotesis pada Tabel 5, dapat dilihat bahwa keterampilan kewirausahaan dan jaringan usaha tidak berpengaruh secara signifikan terhadap kompetensi wirausaha, tetapi variabel orientasi pasar memiliki pengaruh yang positif dan signifikan terhadap kompetensi wirausaha. Penelitian ini juga menunjukkan kompetensi wirausaha tidak mampu memediasi keterampilan wirausaha dan jaringan usaha terhadap kinerja usaha UMKM di Jakarta, tetapi kompetensi wirausaha mampu memediasi orientasi pasar terhadap kinerja usaha UMKM di Jakarta

\section{Diskusi}

\section{Pengaruh keterampilan kewirausahaan terhadap kompetensi wirausaha}

Berdasarkan hasil penelitian, diperoleh bahwa keterampilan kewirausahaan tidak berpengaruh secara signifikan terhadap kompetensi kewirausahaan dengan nilai sampel asli sebesar 0,183 dan nilai $t$-statistics sebesar 1,286. Hal ini tidak sejalan oleh penelitian Barney dan Grant (1991) yang menyatakan adanya manfaat dari keterampilan kewirausahaan bagi kompetensi wirausaha. Hal ini dapat terjadi karena mayoritas dari responden merupakan kalangan milenial yang umurnya dibawah 25 tahun dan juga umur bisnisnya masih antara 1 sampai 2 tahun sehingga mereka belum memiliki keterampilan kewirausahaan yang berdampak terhadap kompetensi kewirausahaannya.

\section{Pengaruh orientasi pasar terhadap kompetensi wirausaha}

Berdasarkan hasil penelitian diketahui orientasi pasar memiliki pengaruh positif dan signifikan terhadap kompetensi kewirausahaan dengan nilai sampel asli sebesar 0,589 dan nilai $t$-statistics sebesar 5,630. Hal ini sejalan oleh penelitian Narver dan Slater (1990) dan penelitian Baker dan Sinkula (2009) yang menggambarkan dengan adanya orientasi pasar maka akan meningkatkan kompetensi wirausaha yang dapat menciptakan nilai superior bagi pembeli. UMKM di Jakarta sudah memiliki orientasi pasar yang dapat mempengaruhi kompetensi kewirausahaan untuk berinovasi.

\section{Pengaruh jaringan usaha terhadap kompetensi wirausaha}

Berdasarkan hasil penelitian selanjutnya diketahui jaringan usaha memiliki pengaruh yang positif tetapi tidak signifikan terhadap kompetensi kewirausahaan dengan nilai sampel asli sebesar 0,047 dan nilai t-statistics sebesar 0,513. Hal ini tidak sejalan dengan penelitian yang dilakukan oleh Bird (1995) dan Ahmad et al. (2010) yang menyatakan jaringan adalah hal yang berharga untuk mengembangkan bisnis. Hal ini dapat terjadi karena menurut Suzie Sugijokanto (2011) pelaku usaha UMKM umumnya masih kurang menganggap penting pembentukan jaringan dan penerapan teknologi informasi (TI), sehingga daya saing masih kurang tangguh.

\section{Pengaruh kompetensi wirausaha terhadap kinerja usaha}

Hasil penelitian juga menjelaskan bahwa kompetensi kewirausahaan berpengaruh positif dan signifikan terhadap kinerja usaha dengan nilai sampel asli sebesar 0,482 dan nilai $t$-statistics sebesar 6,483. Hasil penelitian ini dapat sejalan dengan penelitian oleh Man et al. (2002) dan Gerli et al. (2011) yang menyatakan kompetensi kewirausahaan dikonfirmasi dapat mempengaruhi kinerja usaha secara positif.

Kompetensi kewirausahaan sebagai variabel mediasi keterampilan kewirausahaan, orientasi pasar, jaringan usaha terhadap kinerja usaha

Hasil uji mediasi diketahui kompetensi kewirausahaan mampu memediasi orientasi pasar terhadap kinerja usaha dengan pengaruh yang positif dan signifikan. Hal ini sejalan dengan penelitian yang dilakukan oleh Ie dan Pratama (2019) menemukan bahwa orientasi pasar 
berpengaruh terhadap kinerja usaha. Tetapi berbeda halnya dengan keterampilan kewirausahaan dan jaringan usaha. Berdasarkan hasil uji mediasi diketahui bahwa kompetensi kewirausahaan tidak mampu memediasi keterampilan kewirausahaan dan juga jaringan usaha terhadap kinerja usaha.

\section{KESIMPULAN DAN SARAN}

Berdasarkan hasil penelitian dapat disimpulkan bahwa keterampilan kewirausahaan maupun jaringan usaha tidak berpengaruh secara signifikan terhadap kompetensi wirausaha. Berbeda halnya dengan orientasi pasar memiliki pengaruh yang positif dan signifikan terhadap kompetensi wirausaha. Hasil penelitian juga menunjukkan kompetensi wirausaha tidak mampu memediasi keterampilan wirausaha dan jaringan usaha terhadap Kinerja Usaha UMKM di Jakarta sedangkan kompetensi wirausaha dapat memediasi orientasi pasar terhadap kinerja usaha UMKM di Jakarta. Terdapat beberapa saran dari peneliti bagi para pelaku usaha UMKM seperti diharapkan bagi pemilik usaha untuk lebih meningkatkan keterampilan yang mereka miliki dalam mengelola usaha yang mereka jalankan sehingga usaha yang dijalankan menjadi lebih baik dan berkembang. Pemilik usaha diharapkan menjadi lebih cepat dan tanggap dalam mempromosikan suatu produk sesuai dengan target pasar. Para pemilik usaha UMKM sekiranya bisa dapat memperbanyak jaringan usaha sebab dengan memperbanyak jaringan usaha perkembangan bisnis akan menjadi lebih cepat karena bisa mendapat informasi terbaru dan terakurat. Diharapkan pemilik usaha menjaga komunikasi dengan baik, tetap konsisten, bekerja dengan integritas, serta dapat menerapkan manajemen perusahaan yang baik dengan sesama pengusaha maupun orang lain sehingga dapat membentuk jaringan usaha yang baik.

\section{REFERENSI}

Ahmad, N.H., Ramayah, T., Wilson, C. and Kummerow, L. (2010), "Is entrepreneurial competency and business success relationship contingent upon business environment? A study of Malaysian SMEs", International Journal of Entrepreneurial Behavior and Research, 16(3), 182-203.

Baker, W.E. and Sinkula, J.M. (2009), "The complementary effects of market orientation and entrepreneurial orientation on profitability in small businesses", Journal of Small Business Management, 47(4), 443-464.

Barney, J. (1991), "Firm resources and sustained competitive advantage", Journal of Management, 17(1), 99-120

Bird, B. (1995), "Towards a theory of entrepreneurial competency", Advances in Entrepreneurship, Firm Emergence and Growth, 2(1), 51-72

Birley, S. (1985). The role of networks in the entrepreneurial process. Journal of Business Venturing, 1(1), 107-117

Dita \& Soelaiman, L. (2021). Pengaruh pengambilan resiko, inovasi, proaktif, competitive aggressiveness dan otonomi terhadap kinerja usaha konveksi. Jurnal Manajerial Dan Kewirausahaan, 3(1), 186-195. http://dx.doi.org/10.24912/jmk.v3i1.11304

Elfring, T., and Hulsink, W (2003). Networks in entrepreneurship: The case of high-technology firms. Small Business Economics, 21(4): 409-422

Gates, S., (1999). Aligning Strategic Performance Measures and Results. The Conference Board, New York

Gerli, F., Gubitta, P. and Tognazzo, A. (2011), "Entrepreneurial competencies and firm performance: an empirical study", VIII International Workshop on Human Resource Management Conference Proceedings, Seville

Grant, R.M. (1991), "The resource-based theory of competitive advantage: implications for strategy formulation", California Management Review, 33(3), 114-135. 
Hafsah, M. Jafar. (2004) Upaya Pengembangan Usaha Kecil Dan Menengah (UKM). Diakses dari www.smecda.com.

Ie, M. dan Pratama, V. (2019). Pengaruh Orientasi Kewirausahaan Dan Orientasi Pasar Terhadap Kinerja Pada Usaha Kecil Dan Menengah Sektor Ritel. Jurnal Muara Ilmu Ekonomi dan Bisnis, 3(1), 156-164. http://dx.doi.org/10.24912/jmieb.v3i1.4279

Kim, G., Shin, B., Kim, K.K. and Lee, H.G. (2011), "IT capabilities, process-oriented dynamic capabilities, and firm financial performance", Journal of the Association for Information Systems, 12(7), 487-512.

Kohli, A.K. and Jaworski, B.J. (1990), "Market orientation: the construct, research propositions, and managerial implications", The Journal of Marketing, 54(2), 1-18.

Kutzhanova, N., Lyons, T.S. and Lichtenstein, G.A. (2009), "Skill-based development of entrepreneurs and the role of personal and peer group coaching in enterprise development", Economic Development Quarterly, 23(3), 193-210

Mangkunegara. (2005). Evaluasi Kinerja. Bandung: Refika Aditama.

Man, T.W., Lau, T. and Chan, K.F. (2002), "The competitiveness of small and medium enterprises: a conceptualization with focus on entrepreneurial competencies", Journal of Business Venturing, 17(2), 123-142

Mitchelmore, S. and Rowley, J. (2010), "Entrepreneurial competencies: a literature review and development agenda", International Journal of Entrepreneurial Behavior and Research, 16(2), 92-111

Narver, J.C. and Slater, S.F. (1990), "The effect of a market orientation on business profitability", The Journal of Marketing, 54(4), 20-35.

Phelan, C. \& Sharpley, R. (2012). Exploring Entrepreneurial Skills and Competencies in Farm Tourism. The Journal of The Local Economy Policy Unit, 27 (2), 103-118.

Pyysiäinen, J., Anderson, A., McElwee, G. and Vesala, K. (2006), "Developing the entrepreneurial skills of farmers: some myths explored", International Journal of Entrepreneurial Behavior and Research, 12(1), 21-39.

Sengupta, A. (2011). Network strategy an access to business finance: Indian entrepreneurs in the information and communication technology industry. The Journal of Entrepreneurship, 20(1), 103-126

Shehu, A.M., dan Mahmood, R. (2014). "The Relationship Between Market Orientation and Business Performance of Nigerian SMEs: The Role of Organizational Culture," International Journal of Business and Social Science, 5(9), 159-168

Smith, T. M. \& Reece, J. S. (1999), "The relationship of strategy, fit, productivity and business performance in a services setting." Journal of Operations Management, 17(2), 145-161.

Sukadji, Soetarlinah. (2000). Menyusun dan Mengevaluasi Laporan Penelitian. Jakarta: UIPress

Tehseen, S. and Ramayah, T. (2015), "Entrepreneurial competencies and SMEs business success: the contingent role of external integration", Mediterranean Journal of Social Sciences, 6(1), 50-61.

Vorhies, D.W., Morgan, R.E., and Autry, C.W. (2009). "Product-Market Strategy and the Marketing Capabilities of the Firm: Impact on Market Effectiveness and Cash Flow Performance," Strategic Management Journal, 30(12), 1310- 1334. 